УДК $821.161 .2 “ 18-19 ”$

DOI https://doi.org/10.26661/2414-9594-2020-2-26

\title{
КОНЦЕПЦІї ЖАНРОВОЇ ОРГАНІЗАЦІЇ ЛІРИКИ В ЛІТЕРАТУРОЗНАВСТВІ ХХ СТОЛІТТЯ
}

\author{
Назарець В. М. \\ доктор філологічних наук, професор, \\ завідувач кафедри украӥнської мови та літератури \\ Міжнародний економіко-гуманітарний університет імені академіка Степана Дем'янчука \\ вул. Степана Дем'янчука, 4, Рівне, Украӥна \\ orcid.org/0000-0003-4980-5937 \\ azarets1@rambler.ru \\ Миронюк В. М. \\ кандидат філологічних наук, доцент, \\ дочент кафедри української мови та літератури \\ Міжнародний економіко-гуманітарний університет імені академіка Степана Дем'янчука \\ вул. Степана Дем'янчука, 4, Рівне, Украӥна \\ orcid.org/0000-0002-7746-0959 \\ miron7677@gmail.com
}

\begin{abstract}
Ключові слова: лірика, ліричні жанри, жанрові класифікації, жанрова специифіка, жанрові ознаки.
\end{abstract}

У статті досліджено основні концепції жанрової організації лірики в літературознавстві XX ст. Установлено, що на сучасному етапі розвитку літературознавства однією з найбільш актуальних $є$ проблема теоретичного осмислення жанрової природи ліричного твору, розроблення принципів класифікації ліричних жанрів.

На основі опрацювання фахової літератури з аналізованої проблеми з'ясовано дискусійність не лише питання визначення чітких критеріїв жанрового виокремлення типів ліричних творів, а й проблеми функціонування в ліриці такої цілком усталеної теоретичної категорії, як жанр. Проблематичність чіткої жанрової ідентифікації ліричних творів полягає й у тому, що дослідницькі уявлення про них не є сталими, а історично змінними - не лише через ускладнення парадигми їхньої теоретичної рецепції, але, насамперед, з огляду на історичну рухомість категорії жанру, специфіку його комунікативних настанов та естетичних стратегій, внутрішніх смислових взаємозв'язків між елементами його художньої структури та тематичної спрямованості.

Унаслідок вивчення художньої практики поетів XIX-XX ст. спостережено використання авторською індивідуальністю, попри теоретичні аргументи прибічників концепції жанрової атрофії лірики та, відповідно, авторитарний диктат жанрових вимог, певних жанрових стратегій, що полягають у модифікації відповідно до власних творчих настанов усталених канонів жанрового мислення. Простежено відродження з огляду на зміну теоретичної парадигми літературознавства останніх десятиліть активного інтересу до теорії ліричного жанру, характеру та форм його художньої трансформації в минулій та сьогоденній поетичній практиці. Сучасними літературознавцями розроблено шість основних концепцій, які зумовлюють жанрову специфіку художнього твору особливостями його: 1) форми, 2) змісту, 3) змістово-формальної єдності, 4) історичної генези, 5) літературного функціонування, 6) феноменології сприйняття.

Найбільш усталеною сьогодні концепцією класифікації ліричних творів визнано концепцію їх тематичної класифікації (за характером проблематики, що домінує у творі) та диференціації за ознакою специфіки форми зображення, яку запропонував ще у 70-х роках XX ст. відомий російський літературознавець Г. Поспєлов. У концепції передбачено розмежування таких п’яти типів лірики: 1) медитативної, 2) медитативно-зображальної, 3) описовозображальної, 4) «персонажної», 5) розповідної. Зазначено, що у цій концепції не відображено жанрової специфіки художньої організації ліричного твору. 


\title{
CONCEPTS OF LYRIC POETRY GENRE ORGANIZATION IN LITERATURY CRITICISM OF THE XX CENTURY
}

\author{
Nazarets V. M. \\ Doctor of Philology, Professor, \\ Head of the Department of Ukrainian Language and Literature \\ Academician Stepan Demyanchuk International University of Economics and Humanities \\ Stepan Demyanchuk str., 4, Rivne, Ukraine \\ orcid.org/0000-0003-4980-5937 \\ azarets1@rambler.ru \\ Mironyuk V. M. \\ Candidate of Philology, Associate Professor, \\ Associate Professor at the Department of Ukrainian Language and Literature \\ Academician Stepan Demyanchuk International University of Economics and Humanities \\ Stepan Demyanchuk str., 4, Rivne, Ukraine \\ orcid.org/0000-0002-7746-0959 \\ miron7677@gmail.com
}

Key words: lyrics, lyrical genres, genre classifications, genre specificity, genre features.
The article examines the basic concepts of lyrics genre organization in literary criticism of the XX century. It is established that at the present stage of development of literary criticism one of the most relevant is the problem of theoretical understanding of the genre nature of the lyrical work, the development of principles for the classification of lyrical genres.

Based on the study of professional literature on the analyzed problem not only the question of defining clear criteria for genre separation of types of lyrical works, but also the problem of functioning in lyric poetry of such a well-established theoretical category as genre has been clarified. The problem of clear genre identification of lyrical works is that researchers ideas about them are not stable, but historically variable not only because of the complexity of the paradigm of their theoretical reception, but primarily because of the historical mobility of the genre, the specificity of its communicative guidelines and aesthetic strategies, internal semantic relationships between elements of its artistic structure and thematic focus.

As a result of studying the artistic practice of poets of the XIX-XX centuries the use of authorial individuality, despite the theoretical arguments of supporters of the concept of genre atrophy of lyrics and, accordingly, the authoritarian dictate of genre requirements, certain genre strategies, consisting in modification in accordance with their own creative guidelines established canons of genre thinking is observed. Revival in view of the change of the theoretical paradigm of literary criticism of the last decades of active interest in the theory of lyrical genre, character and forms of its artistic transformation in the past and present poetic practice is traced. Modern literary critics have developed six basic concepts that determine the genre specificity of a work of art by such features: 1) form, 2) content, 3) semantic-formal unity, 4) historical genesis, 5) literary functioning, 6) phenomenology of perception.

The most established concept of classification of lyrical works today is the concept of their thematic classification (by the nature of the issues that dominate the work) and differentiation on the basis of the specific form of the image, proposed in the 70s of the twentieth century by the famous Russian literary critic G. Pospelov. The concept provides for the delimitation of the following five types of poetry: 1) meditative, 2) meditative-figurative, 3) narrative-figurative, 4) «character's» 5) narrative. It is noted that this concept does not reflect the genre specifics of the artistic organization of the lyrical work. 
Постановка проблеми. Питання про природу та специфіку ліричного жанру - це складова частина спектру вагомих і водночас найбільш дискусійних питань сучасного літературознавства. Про нагальність цього питання дає підстави стверджувати не лише нерозробленість чітких критеріїв жанрового виокремлення тих або інших типів ліричних творів, а й загалом дискусійність питання про правомірність використання такої, здавалося б, цілком усталеної категорії, як жанр у ліриці [6, с. 10].

Окремі дослідники (Ю. Тинянов, Б. Ейхенбаум, В. Шкловський, В. Жирмунський, Г. Поспєлов, Л. Тимофєєв, С. Бройтман, Н. Тамарченко, В. Тюпа, О. Зирянов та ін.) констатують посилення інтересу до проблеми жанру в сучасному літературознавстві і набуття ними методологічної значущості у дослідженні твору як цілісної системи.

Мета статті полягає у тому, щоб дослідити концепції жанрової організації лірики в сучасному літературознавстві.

Виклад основного матеріалу. Із періоду античності й упродовж наступних літературних епох у площині розроблення принципів ліричного жанроутворення детермінантами жанрової диференціації ліричних творів виступали дві домінуючі, достатньо чітко означені тенденції: тенденція визначення жанру ліричного твору за характером виявлених у ньому авторських емоцій (авторської чи емоційної модальності, або пафосу) та тенденція визначення жанру твору за типом тематики (життєвої події, факту, обставин, які стали приводом для написання твору) [6, с. 11]. Шляхом формування у процесі історичного розвитку ці тенденції поступово стали визначальними, а в період XVII-XVIII ст., тобто в епоху панування класицизму, набули статусу нормативних із погляду жанроутворення.

Жанрове «обличчя» ліричних творів романтиків зазнало таких значних змін, що з ініціативи одного $з$ найбільш авторитетних на той час теоретиків літератури В. Бєлінського в літературному середовищі набув поширення вислів про «відмирання», «атрофію» ліричних жанрів.

Утім, концепцію жанрової атрофії не було визнано визначальною ні в українському, ні в зарубіжному літературознавстві. Натомість упродовж XX ст. вчені розробили значну кількість конщепцій, у яких не заперечено, а навпаки, доведено жанрову природу художнього твору, втім, по-різному визначено ії сутність. Найбільш відомими 3 таких концепцій $є$ концепції, у яких жанрова специфіка художнього твору детермінована особливостями його: 1) форми, 2) змісту, 3) змістовно-формальної єдності, 4) історичного генезису, 5) літературного функціонування, 6) феноменології його сприйняття.

1. Формалістична концепція жанру. Підгрунтям формалістичної концепції жанру слугують праці представників формальної школи літературознавства 1920-х років, насамперед теоретичні розвідки Б. Томашевського, В. Шкловського, Ю. Тинянова. На думку цих науковців, жанрову специфіку літературного твору зумовлюють передусім його формальні, структурно-композиційні особливості. Так, Б. Томашевський окреслював жанр твору за допомогою уведеного ним поняття домінанти: «Ознаки жанру, тобто прийоми, які організують композиційно твір, $є$ прийомами домінантними, тобто такими, що підпорядковують собі решту, необхідну для створення художнього цілого. Такий домінуючий, превалюючий прийом іноді називають домінантою. Сукупність домінант і $є$ основним моментом в утворенні жанру» [9, с. 207]. Схожі думки висловлював В. Шкловський, який уважав жанр усталеною, повторюваною комбінацією тих або інших композиційних одиниць та стильових мотивів.

2. Змістовна концепція жанру. Сутність змістовної концепції жанру полягає у регламентації в статусі основних чинників жанротворення не формальних, а змістових, проблемно-тематичних чинників художнього твору.

Найбільш послідовним прихильником змістовної концепції жанру був відомий радянський літературознавець Г. Поспєлов, який підкреслював, що «родові та жанрові властивості творів - це не властивості їхньої форми, що виражає зміст, це типологічні властивості самого їхнього художнього змісту» $[7$, с. 206]. У контексті побудови власної типології жанрів Г. Поспєлов розмежовував поняття «жанрового змісту» $\mathrm{i}$ «жанрової форми». Сутність поняття «жанровий зміст» він тлумачив як «історично повторюваний аспект проблематики творів художньої словесності» [8, с. 166] і розрізняв чотири зумовлені історично різновиди жанрового змісту: міфологічний, етологічний, національно-історичний, романтичний.

Змістовна концепція жанру набула статусу «офіційної» у сфері радянського літературознавства, її активно підтримували багато вчених-теоретиків.

3. Змістовно-формальна концепція жанру. На відміну від прихильників двох попередніх жанрових концепцій, які підкреслювали домінування формальних або змістовних чинників жанротворення, представники змістовно-формальної теорії намагалися їх урівноважити. Так, відомий літературознавець I. Кузьмичов у науковій розвідці «Літературне перехрестя», присвяченій типології жанрів у їх історичному розвитку, головним чинником, що впливає на жанроутворення, називає «методологію художнього мислення». Цю категорію він трактує як «історично сформований і самою епохою зумовлений творчий метод», за допомогою якого «жанрові форми підпорядковують відповідним естетичним запитам сьогодення» [4, с. 119]. 
Специфіку жанрової організації твору представники цієї концепції (Д. Благой, І. Стеблєва та ін.) схильні вбачати безпосередньо у характері зв'язків між формальними та змістовними компонентами твору, що призводить до інтерпретації жанру як своєрідного інструменту «зчеплення» змісту та форми.

4. Генетична концепція жанру. Суттєвим недоліком трьох попередніх концепцій жанру є те, що всі вони переважно відзначаються намаганням окреслити жанр як певне статичне утворення, без урахування динаміки змін останнього у процесі його історичної трансформації. Теоретичні аспекти жанроутворення в площині його історичного генезису було розроблено у працях відомих учених О. Фрейденберг, В. Проппа, Д. Лихачова, М. Бахтіна, С. Мелетинського та ін.

5. Функційна концепція жанру. За словами Т. Боровської, «за генетичного підходу до жанру залишається невирішеним питання про розвиток жанрів та їх функціонування: чому одні жанри переважають на певній фазі літературного розвитку, а потім йдуть на периферію, «вмирають», щоб поступитися місцем іншим (а іноді знову відроджуються)» $[2$, с. 31$]$.

Осмислення функційної концепції жанру представлено у наукових студіях Н. Лейдермана, Л. Суботіна, С. Баранова, О. Казаркіна, С. Страшнова. Названі дослідники інтерпретували категорію жанру як інструмент мікромоделювання. Найбільш чітко тезу про мікромоделюючу роль жанру обгрунтовано у теоретичних працях Н. Лейдермана. Як він сам зауважував, «ще в середині 70-х років мною було висунуто ідею про те, що жанр забезпечує конструктивну єдність твору, він «відповідає» за організацію всіх його «будівельних» елементів у модель світу. Звідси формулювання: жанр - це система принципів і способів художньої завершеності, тобто організації твору в цілісний образ світу (модель світу, «мікро-Всесвіт»), у якому втілено естетичну концепцію людини і світу» [5, с. 7-8]. У контексті побудови власної жанрової класифікації вчений пропонує виділяти такі структурно-семантичні параметри: жанровий зміст, форму і сприйняття.

6. Феноменологічна концепція жанру. Феноменологічна концепція - одна 3 найсучасніших жанрових концепцій, яку водночас можна вважати логічним продовженням ідей функційного підходу до інтерпретації жанрової специфіки художнього твору. Найбільш послідовним теоретиком та прихильником феноменологічної жанрової концепції є О. Зирянов, який формулює основні іï методологічні засади так: «По-перше, жанр не слід трактувати як виконання теоретичного апріорі якоїсь наперед визначеної абстрактної сутності, жанр - це насамперед явище, зумовлене конкретно-історичними зрушеннями художньої свідомості, продукт літературної еволюції, що неминуче вимагає від дослідника (історика чи теоретика літератури) обов'язкового виходу у сферу історичної поетики. По-друге, жанр існує і виявляє себе не в узагальненій жанровій моделі (певному абстрактному інваріанті), а в «суті життя твору» (термін-метафора M.M. Бахтіна), інакше - у різноманітті індивідуальних жанрових форм. А це вже в обов'язковому порядку підводить до трактування жанру як необхідної основи, ціннісно-естетичної запоруки виникнення, розгортання та завершення художньої цілісності, як неодмінної категорії художнього мислення i, ширше, феноменології художньої свідомості, зрештою - як найважливішого чинника літературної еволюції» [3, с. 12].

$\mathrm{y}$ контексті феноменологічного осмислення жанрової природи твору особливого значення набуває аналіз авторських жанрових інтенцій i особливо рефлексій (авторської феноменології жанру), а також специфіки читацької жанрової рецепції.

Питання жанрології впродовж XX ст. було предметом наукових пошуків представників англо-американського та західноєвропейського літературознавства. Так, якщо, за спостереженнями дослідників, у першій половині XX ст. у західній жанрології домінуючими були проблеми пошуку теоретичних аргументів для чіткої диференціації основних літературних родів (епос, лірика, драматургія) та систематизації належних до кожного 3 них жанрів, то 3 другої половини $\mathrm{XX}$ ст. набули пріоритетності саме жанрові проблеми, інтерпретовані у площині і літературних, i міждисциплінарних аспектів їх вияву. Як зауважує дослідник західної жанрології Т. Бовсунівська, «провідними тенденціями інтерпретації жанру стали пробахтинська (Ц. Тодоров, К. Емерсон, Г.С. Морсон та ін.), типологічна, переважно з гегельянським підгрунтям (М. Адамс, Х. Дуброу та ін.), неоаристотелівська, формалістична за своєю сутністю (Е. Олсон, Чиказька школа, Ж. Женетт та ін.), психологічна, різноманітна у розгалуженнях (П. ван Тігем, П. Гернаді та ін.), структуралістська (Дж. Каллер, Р. Уеллек, О. Уоррен та ін.) тощо» [1, с. 64-65].

Висновки і перспективи подальших досліджень у даному напрямі. У статті досліджено основні концепції жанрової диференціації ліричних творів, детерміновані особливостями їхньої: 1) форми, 2) змісту, 3) змістовно-формальної єдності, 4) історичного генезису, 5) літературного функціонування, 6) феноменології їхнього сприйняття.

Подальшого дослідження очікують питання системно-цілісного аналізу жанрової природи ліричного твору. 


\section{ЛІТЕРАТУРА}

1. Бовсунівська Т.В. Теорія літературних жанрів: жанрова парадигма сучасного зарубіжного роману : підручник. Київ : Київський університет, 2009. 519 с.

2. Боровская А.А. Жанровые трансформации в русской поэзии первой трети $\mathrm{XX}$ века : дис. ... докт. филолог. наук : 10.01.01. Астрахань, 2009. 527 с.

3. Зырянов О.В. Пролегомены в феноменологическую теорию жанра. Жанрологический сборник. 2004. Вып. 1. С. 12-16.

4. Кузьмичев И.К. Литературные перекрестки (Типология жанров, их историческая судьба). Горький : Волго-Вятское книжное издательство, 1983. 208 с.

5. Лейдерман Н.Л. Проблема жанра в модернизме и авангарде. (Испытание жанра или испытание жанром?). Русская литература XX-XXI веков: направления и течения. 2006. Вып. 9. С. 3-33.

6. Назарець В.М. Жанрові модифікації української адресованої лірики. Рівне : О. Зень, 2014. 384 с.

7. Поспелов Г.Н. Вопросы методологии и поэтики. Москва : Московский университет, 1983. 206 с.

8. Поспелов Г.Н. Проблемы исторического развития литературы. Москва : Просвещение, 1972. $272 \mathrm{c.}$

9. Томашевский Б.В. Теория литературы. Поэтика : учебное пособие. Москва : Аспект Пресс, 1999. 334 c.

\section{REFERENCES}

1. Bovsunivska T.V. (2009), [Theory of literary genres: genre paradigm of the modern foreign novel] Teoriya literaturnyx zhanriv: zhanrova paradygma suchasnogo zarubizhnogo romanu: pidruchnyk. K. : «Kyyivskyj universytet» [in Ukrainian].

2. Borovskaya A.A. (2009), [Genre transformations in Russian poetry of the first third of the $20^{\text {th }}$ century] Zhanrovyie transformatsii v russkoy poezii pervoy treti XX veka. Astrahan. [in Russian].

3. Zyiryanov O.V. (2004), [Prolegomena to the phenomenological genre theory] Prolegomenyi v fenomenologicheskuyu teoriyu zhanra. Zhanrologicheskiy sbornik. Vypusk 1. Elets: EGU imeni I. A. Bunina, 2004. S. 12-16. [in Russian].

4. Kuzmichev I.K. (1983), [Literary Crossroads] Literaturnyie perekrestki (Tipologiya zhanrov, ih istoricheskaya sudba). Gorkiy: Volgo-Vyatskoe knizhnoe izdatelstvo [in Russian].

5. Leyderman N.L. (2006), [Genre problems of the modernism and vanguard] Problema zhanra v modernizme i avangarde. (Ispyitanie zhanra ili ispyitanie zhanrom?). Russkaya literatura XX-XXI vekov: napravleniya $i$ techeniya. Izdatelstvo Uralskogo gosudarstvennogo pedagogicheskogo universiteta, 2006. Vyp. 9. S. 3-33. [in Russian].

6. Nazarets V.M. (2014), [Genre Modifications of Ukrainian Addressed Lyric Poetry] Zhanrovi modifikatsii ukrainskoi adresovanoi liryky. Rivne : O. Zen [in Ukrainian].

7. Pospelov G.N. (1983), [Problems of methodology and poetics] Voprosyi metodologii i poetiki. M. : Izdatelstvo Moskovskogo universiteta [in Russian].

8. Pospelov G.N. (1972), [Problems of historical development of literature] Problemyi istoricheskogo razvitiya literaturyi. M. : Prosveschenie. [in Russian].

9. Tomashevskiy B.V. (1999), [Theory of Literature. Poetics] Teoriya literaturyi. Poetika : uchebnoe. posobie. M. : Aspekt Press. [in Russian]. 